\title{
EFFECT OF BIO-FERTILIZATION AND GROWING MEDIA ON THE CHEMICAL COMPOSITION OF MORINGA OLEIFERA TREES
}

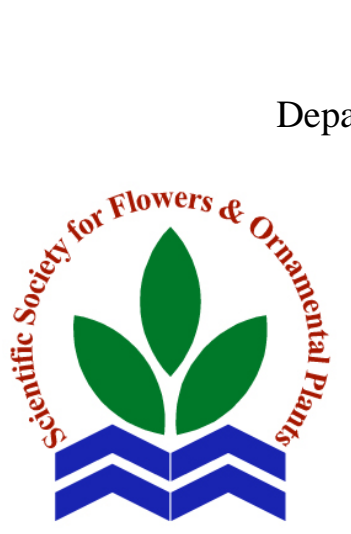

Scientific J. Flowers \& Ornamental Plants, 4(2):199-208 (2017).

Received:

21/5/2017

Accepted: $31 / 5 / 2017$

\author{
A.Z. Sarhan, Azza M.S. Arfa and H.A. Gonaw
}

Department of Ornamental Horticulture, Cairo Univ., Giza, Egypt.

ABSTRACT: The experimental trial was consummated at the nursery of Ornamental Horticulture Department, Fac. Agric., Cairo University, Giza, Egypt during two successive seasons of 2014 and 2015 to study the effect of growing media (sand, clay and mixture (sand + clay at 1:1 $\mathrm{v} / \mathrm{v}$ ) and bio-fertilization (microbine, green power and potasiomag) with $200 \mathrm{ml} /$ pot on the chemical composition of Moringa oleifera (chlorophyll a, b, a + b, carotenoids, carbohydrates and mineral elements (N, P and $\mathrm{k} \%$ ).

The results showed that the highest leaf contents of chlorophyll a, b and carotenoids, carbohydrates and leaf $\mathrm{N}, \mathrm{P}$ and $\mathrm{K} \%$ were obtained from the most suitable media (sand + clay at $1: 1 \mathrm{v} / \mathrm{v}$ ) combined with biofertilization (microbine, green power and potasiomag).

Key words: Moringa oleifera, soil type, bio-fertilizer, chemical composition, pigments, mineral elements.

\section{INTRODUCTION}

Moringa oleifera Lam. is one of the most important trees in the tropical and semi-tropical regions in terms of economic importance. It belongs to Moringaceae family and has positive effects on human health. It is also used in a medicine and feeding for animals. It is also a fast growing plant (Amaglo et al., 2007; Peixoto et al., 2011; Pontual et al., 2012).

Seeds of Moringa oleifera are used as a natural coagulant of raw water clarification, the powder of crushed seed kernels can leave water clear with 90:99\% of the bacteria removed (Sutherland et al., 1989). Also the seeds are used for oil production, which is used in cosmetics and medicine.

Many researchers studied the effect of bio and chemical fertilization and growing media on growth and chemical composition of Moringa oleifera (pigments: chlorophyll a and $b$, carbohydrates and mineral elements of $\mathrm{N}, \mathrm{P}$ and $\mathrm{K}$ in the leaves). In this regard ElSayed (2013) on Moringa oleifera found that, using the mixture of sand + loam + compost (1:1:1), sand + loam (1:1) and loam alone had a favorable effect on increasing the content of pigments, total carbohydrates and nutrients (nitrogen, phasphoras, potassium and sodium comparing with other growing media).

Dash and Gupta (2009) and Asaolu et al. (2012) on Moringa oleifera concluded that bio fertilizers treatments significantly increased pigments compared with control.

The objective of this study is to explain the effect of bio-fertilization and the growing media on the chemical constituents: pigment content, carbohydrate and the mineral elements ( $\mathrm{N}, \mathrm{P}$ and $\mathrm{K}$ ) in Moringa oleifera leaves.

\section{MATERIALS AND METHODS}

This investigation was carried out during the two successive seasons of 2014 and 2015 at the nursery of Ornamental Horticulture Department, Faculty of Agriculture, Cairo University, Giza. The investigation aimed to evaluate the effect of the type of medium, bio-fertilizer (microbine, green power and 


\section{A.Z. Sarhan et al.}

potasiomag) and their interaction on chemical composition of Moringa oleifera.

The seeds of Moringa oleifera were obtained from the National Research Center, Dokki, Giza. The seeds were sown in unheated greenhouse, on February, $15^{\text {th }}$ for the two experimental seasons in $15 \mathrm{~cm}$ diameter pots filled with clayey/sandy soil $(1: 1 \mathrm{v} / \mathrm{v})$. The seedlings were transplanted on March, $15^{\text {th }}$ in both seasons in plastic pots of $25 \mathrm{~cm}$ diameter filled with soil [clay, sand and sand + clay $(1: 1 \mathrm{v} / \mathrm{v})]$.

The first inoculation of bio-fertilization (microbine, green power and potasiomag) began after one month from transplanting and the second after 6 months, using liquid fertilizer with $200 \mathrm{ml} /$ pot (microbine, green power and potasiomag).

The layout of the experiment was a factorial in a randomized complete block design with three replicates.

Soil physical and chemical analyses were carried out using the procedures described by Black et al. (1981), and by Cottenie et al. (1982), Table (a).

The recorded data on chemical composition parameters were: chlorophyll a (mg/g f.w.), chlorophyll b (mg/g f.w.), chlorophyll a + b (mg/g f.w.), carotenoids content (mg/g f.w.), total carbohydrates (\%), nitrogen (\%), phosphorus (\%) and potassium (\%).

\section{RESULTS AND DISCUSSION}

\section{Effect of bio fertilization and growing media on:}

1. Pigments content in the leaves:

\section{a. Chlorophyll a (mg/g f.w.):}

Data presented in Table ranged between 0.69 to $2.21 \mathrm{mg} / \mathrm{g}$ f.w. in the first season and from 0.69 to $1.61 \mathrm{mg} / \mathrm{g}$ f.w. in the second one when treated with different biofertilizers. Plants treated with microbial fertilizer resolved at the highest chlorophyll a content $(2.21$ and $1.61 \mathrm{mg} / \mathrm{g}$ f.w. in the first and second seasons respectively compared to the control plants that gave the lowest values (0.69 $\mathrm{mg} / \mathrm{g}$ f.w. in the two seasons, respectively).

Data presented in Table (1) revealed that application of growing medium led to inducing the leaf content of chlorophyll a. According to the recorded data in Table (1), sand + clay soil produced the highest value of chlorophyll a content $(1.84$ and $1.47 \mathrm{mg} / \mathrm{g}$ f.w., in the first and second seasons, respectively). These results are in line with the findings of Watfa (2009) on Aleppo pine seedling, which found that the mixture of sand + clay was the most effective media for increasing the contents of chlorophyll a in the leaves.

Regarding effect of the interaction between growing medium and biofertilizer treatments data presented in Table (1) showed that, plants grown in sand + clay soil when combining with green power treatment produced plants with more chlorophyll a content in their tissues (2.65 $\mathrm{mg} / \mathrm{g} \mathrm{f.w.)}$ in the first season. In the second season, plants grown in clay soil + sand with fertilization with green power also gave highest values of $2.08 \mathrm{mg} / \mathrm{g} \mathrm{f.w}$. while the lowest mean values of chlorophyll a 0.36 $\mathrm{mg} / \mathrm{g} \mathrm{f.w}$. in the first and second seasons, respectively, were recorded from plants grown in sandy + clayey soil without fertilization.

demonstrated that chlorophyll a content

Table a. physical and chemical analyses of the used soil.

\begin{tabular}{|c|c|c|c|c|c|c|c|c|c|c|}
\hline \multirow{2}{*}{ No. } & \multirow{2}{*}{$\mathbf{p H}$} & \multirow{2}{*}{$\mathbf{E C}$} & \multicolumn{4}{|c|}{ Soluble anions (meq/L) } & \multicolumn{4}{c|}{ Soluble cations (meq/L) } \\
\cline { 4 - 11 } & & $\mathbf{d S} / \mathbf{m}$ & $\mathbf{C O}_{3}$ & $\mathbf{H C O}_{3}$ & $\mathbf{C l}$ & $\mathbf{S O}_{\mathbf{4}}$ & $\mathbf{C a}$ & $\mathbf{M g}$ & $\mathbf{K}$ & $\mathbf{N a}$ \\
\hline 1 & 8.36 & 0.28 & - & 1.6 & 1.6 & $\mathrm{Nil}$ & 1.0 & 0.2 & 0.128 & 0.89 \\
\hline 2 & 7.95 & 1.79 & 0.8 & 4.2 & 8.6 & 4.1 & 7.5 & 4.0 & 2.34 & 3.86 \\
\hline
\end{tabular}


Table 1. Effect of growing media and fertilization treatment on chlorophyll a (mg/g f.w.) of Moringa oleifera plants during 2014 and 2015 seasons.

\begin{tabular}{|c|c|c|c|c|c|c|c|c|}
\hline \multicolumn{9}{|c|}{$\begin{array}{c}\text { Growing media (B) } \\
\text { Chlorophyll a (mg/g f.w.) }\end{array}$} \\
\hline \multirow[b]{2}{*}{ Fertilizer (A) } & \multicolumn{4}{|c|}{2014} & \multicolumn{4}{|c|}{2015} \\
\hline & Sandy & Clayey & $\begin{array}{c}\text { Sandy \& } \\
\text { Clayey }\end{array}$ & Mean (A) & Sandy & Clayey & $\begin{array}{c}\text { Sandy \& } \\
\text { Clayey }\end{array}$ & Mean (A) \\
\hline Control & 1.20 & 0.50 & 0.36 & 0.69 & 1.20 & 0.50 & 0.36 & 0.69 \\
\hline Microbine & 2.31 & 1.79 & 2.53 & 2.21 & 1.77 & 1.29 & 1.76 & 1.61 \\
\hline Green power & 1.74 & 1.88 & 2.65 & 2.09 & 1.34 & 1.25 & 2.08 & 1.56 \\
\hline Potasiomag & 1.76 & 1.94 & 1.83 & 1.84 & 1.50 & 1.38 & 1.66 & 1.51 \\
\hline Mean (B) & 1.75 & 1.53 & 1.84 & & 1.45 & 1.11 & 1.47 & \\
\hline LSD at 0.05 of $A$ & & 0.57 & & & & 0.32 & & \\
\hline LSD at 0.05 of $B$ & & 0.45 & & & & 0.25 & & \\
\hline LSD at 0.05 of $A \times B$ & & 0.65 & & & & 0.50 & & \\
\hline
\end{tabular}

\section{b. Chlorophyll b (mg/g f.w.):}

Data presented in Table (2) revealed that chlorophyll b content was affected by biofertilization treatments. Control plants had the lowest chlorophyll b content $(0.10$ and $0.13 \mathrm{mg} / \mathrm{g}$ f.w. in the first and second seasons, respectively). When microbine was used, it increased the chlorophyll b content to reach its maximum values of 0.43 and $1.08 \mathrm{mg} / \mathrm{g} \mathrm{f.w}$. in the first and second seasons, respectively. Increasing the leaves content of chlorophyll b by using biofertilizer was observed by Arafa (2005) on senna.

Data presented in Table (2) revealed that the treatment of clay soil significantly increased the chlorophyll b content of Moringa oleifera in comparison with uninoculated plants. The highest content of chlorophyll b $(0.50 \mathrm{mg} / \mathrm{g}$ f.w. in the first season and $0.84 \mathrm{mg} / \mathrm{g} \mathrm{f.w}$. in second one) were obtained when the plants were planted in clayey soil and followed by the treatment with sand soil (giving values of 0.23 and $0.52 \mathrm{mg} / \mathrm{g} \mathrm{f.w}$. in the first and second seasons respectively).

The lowest values of chlorophyll b were obtained as 0.18 and $0.37 \mathrm{mg} / \mathrm{g} \mathrm{f.w}$. in the first and second seasons, respectively, in mixture of sand and clay soil. These results are in line with their findings of Abd ElAziz (2000) on Azadirachta indica seedlings.

Regarding the effect of interaction between soil and biofertilization treatments on the content of chlorophyll b data revealed that the values obtained were different. In the first season, the plants grown in clayey soil and fertilized with microbine had a higher content $(0.82 \mathrm{mg} / \mathrm{g}$ f.w.) as compared with control which gave value of $0.10 \mathrm{mg} / \mathrm{g}$ f.w. In the second season the maximum value of chlorophyll b (1.35 mg/g f.w.) was recorded in the plants treated with green power and planted in clayey soil. On the other hand, the lowest value $(0.08 \mathrm{mg} / \mathrm{g}$ f.w.) was recorded from growing plants in sandy + clayey soil without fertilization.

\section{c. Total Chlorophylls a + b (mg/g f.w.):}

Data presented in Table (3) show that, the biofertilization treatments used in this study increased the total chlorophyll in leaves of Moringa oleifera compared whit control. The values ranged from 2.17 to 2.64 in the first season and 1.93 to $2.68 \mathrm{mg} / \mathrm{g} \mathrm{f.w}$. in the second one.

The highest values were recorded in fertilized plants with microbine (2.64 and $2.68 \mathrm{mg} / \mathrm{g} \mathrm{f.w}$. in the first and second seasons, respectively). While the lowest values were obtained in untreated plants (no 


\section{A.Z. Sarhan et al.}

Table 2. Effect of growing media and fertilization treatment on chlorophyll b (mg/g f.w.) of Moringa oleifera plants during 2014 and 2015 seasons.

\begin{tabular}{|c|c|c|c|c|c|c|c|c|}
\hline \multicolumn{9}{|c|}{$\begin{array}{c}\text { Growing media (B) } \\
\text { Chlorophyll b (mg/g f.w.) }\end{array}$} \\
\hline \multirow[b]{2}{*}{ Fertilizer (A) } & \multicolumn{4}{|c|}{2014} & \multicolumn{4}{|c|}{2015} \\
\hline & Sandy & Clayey & $\begin{array}{c}\text { Sandy \& } \\
\text { Clayey }\end{array}$ & Mean (A) & Sandy & Clayey & $\begin{array}{c}\text { Sandy \& } \\
\text { Clayey }\end{array}$ & Mean (A) \\
\hline Control & 0.12 & 0.10 & 0.08 & 0.10 & 0.13 & 0.15 & 0.10 & 0.13 \\
\hline Microbine & 0.25 & 0.82 & 0.21 & 0.43 & 1.17 & 1.21 & 0.85 & 1.08 \\
\hline Green power & 0.24 & 0.64 & 0.19 & 0.36 & 0.50 & 1.35 & 0.22 & 0.69 \\
\hline Potasiomag & 0.32 & 0.44 & 0.23 & 0.33 & 0.28 & 0.64 & 0.32 & 0.41 \\
\hline Mean (B) & 0.23 & 0.50 & 0.18 & & 0.52 & 0.84 & 0.37 & \\
\hline LSD at 0.05 of $A$ & & 0.42 & & & & 0.24 & & \\
\hline LSD at 0.05 of $B$ & & 0.33 & & & & 0.31 & & \\
\hline LSD at 0.05 of $A \times B$ & & 0.51 & & & & 0.48 & & \\
\hline
\end{tabular}

Table 3. Effect of growing media and fertilization treatment on chlorophyll $\mathbf{a}+\mathbf{b}$ (mg/g f.w.) of Moringa oleifera plants during 2014 and 2015 seasons.

\begin{tabular}{|c|c|c|c|c|c|c|c|c|}
\hline \multicolumn{9}{|c|}{$\begin{array}{c}\text { Growing media (B) } \\
\text { Chlorophyll a+b (mg/g f.w.) }\end{array}$} \\
\hline \multirow[b]{2}{*}{ Fertilizer (A) } & \multicolumn{4}{|c|}{2014} & \multicolumn{4}{|c|}{2015} \\
\hline & Sandy & Clayey & $\begin{array}{c}\text { Sandy \& } \\
\text { Clayey }\end{array}$ & Mean (A) & Sandy & Clayey & $\begin{array}{c}\text { Sandy \& } \\
\text { Clayey }\end{array}$ & Mean (A) \\
\hline Control & 1.32 & 0.60 & 0.44 & 0.79 & 1.33 & 0.65 & 0.46 & 0.81 \\
\hline Microbine & 2.56 & 2.61 & 2.74 & 2.64 & 2.94 & 2.50 & 2.61 & 2.68 \\
\hline Green power & 1.98 & 2.52 & 2.84 & 2.45 & 1.84 & 2.60 & 2.30 & 2.25 \\
\hline Potasiomag & 2.08 & 2.38 & 2.06 & 2.17 & 1.78 & 2.02 & 1.98 & 1.93 \\
\hline Mean (B) & 1.99 & 2.03 & 2.02 & & 1.97 & 1.94 & 1.84 & \\
\hline LSD at 0.05 of $A$ & & 0.65 & & & & 0.49 & & \\
\hline LSD at 0.05 of $B$ & & 0.51 & & & & 0.38 & & \\
\hline LSD at 0.05 of $A \times B$ & & 0.123 & & & & 1.05 & & \\
\hline
\end{tabular}

fertilization) which gave $(0.79$ and $0.81 \mathrm{mg} / \mathrm{g}$ f.w. in the first and second seasons, respectively).These results are in line with what they came from El-Sayed and Abdou (2002) on Khaya senegalensis transplants who reported that sandy + loam + sewage sludge soil as well as biofertilizer application with Azotobacter chroococcum every 15 days increased the total chlorophyll contents of the leaves.

Presented data in Table (3) show that the total chlorophylls content was considerably affected by growing medium. In the first season the highest total chlorophylls (2.03 $\mathrm{mg} / \mathrm{g}$ f.w.) were recorded in the plants that were grown in clayey soil followed by sandy + clayey soil which gave $2.02 \mathrm{mg} / \mathrm{g}$ f.w. The least values $(1.99 \mathrm{mg} / \mathrm{g}$ f.w. in the first season) were noticed with the plants grown in sandy soil. In the second season it was found that sandy soil gave the highest values (1.97 mg/g f.w.) followed by clayey soil (1.94 mg/g f.w.) while the lowest values were found in the sandy + clayey soil (1.84 $\mathrm{mg} / \mathrm{g} \mathrm{f.w.).} \mathrm{These} \mathrm{results} \mathrm{are} \mathrm{in} \mathrm{line} \mathrm{with}$ those of El- Sayed and Abdou (2002) on Khaya senegalensis transplants who found that sandy + loam + sewage sludge soil 
increased total chlorophyll contents of the leaves.

As for the combination effect of biofertilization and soil type data presented in Table (3) also showed that, all the treatments gave higher mean total chlorophylls content $(2.84 \mathrm{mg} / \mathrm{g} \mathrm{f.w}$. in the first season for grown plants in sandy + clayey soil and treated with green power and $2.94 \mathrm{mg} / \mathrm{g} \mathrm{f.w}$. in the second season for sandy soil and treated with microbine) than growing plants in sandy + clayey soil without fertilization which recorded 0.44 and $0.46 \mathrm{mg} / \mathrm{g}$ f.w. in the first and second seasons, respectively.

\section{d. Carotenoids content (mg/g f.w.):}

Data presented in Table (4) showed that, the carotenoids content was increased as a result of using biofertilization treatments compared with control in the two seasons. Application of green power increased carotenoids content to $1.76 \mathrm{mg} / \mathrm{g} \mathrm{f.w}$. in the first season and $1.39 \mathrm{mg} / \mathrm{g} \mathrm{f.w}$. in the second one than that of control plants which gave the lowest values of 0.51 and $0.31 \mathrm{mg} / \mathrm{g}$ f.w. in the first and second seasons, respectively.

As for the effect of the soil type, data in the first season showed that sandy soil gave the highest values $(1.78 \mathrm{mg} / \mathrm{g} \mathrm{f.w.})$ followed by sandy + clayey soil (1.24 mg/g f.w.). In the second season, the highest values were obtained also in sandy soil (1.39 $\mathrm{mg} / \mathrm{g} \mathrm{f.w.)}$ then clayey soil $(0.72 \mathrm{mg} / \mathrm{g}$ f.w. $)$ while the lowest results were obtained in sandy + clayey soil ( $0.70 \mathrm{mg} / \mathrm{g}$ f.w.)

Regarding the effect of type soil when combined with biofertilization treatments on the content of carotenoids, data revealed that plants grown in sandy soil with green power had a higher content (2.52 and $1.97 \mathrm{mg} / \mathrm{g}$ f.w. in the first and second seasons, respectively). On the other hand, the lowest value which was recorded in the first season (0.34 mg/g f.w.) was recorded by control plants with sandy + clayey soil. In the second season the lowest value $(0.26 \mathrm{mg} / \mathrm{g}$ f.w.) was also obtained from control plants with sandy soil.

\section{Total carbohydrates $\%$ in the leaves:}

Data presented in Table (5) revealed that biofertilization had a significant effect on the leaves carbohydrates \% during the two seasons. Plants which received biofertilization treatments at different rates produced leaves carbohydrates percentages ranged between 21.70 to $25.79 \%$ in the first season and 21.37 to $26.1 \%$ in the second one. Leaves of control plants contained (18.82 and $18.31 \%$ in the first and second seasons, respectively), as total carbohydrates.

The highest percentage of leaves carbohydrates (25.79 and $26.10 \%$ in the first and second seasons, respectively) were recorded with potasiomag, whereas the same potasiomag insignificantly increased the leaves content of carbohydrates with nonsignificant differences compared to other biofertilization treatments and it was significant compared to control. These results are consistent with what have achieved by Kumudha (2005) on Acacia nilotica.

Regarding the effect of soil type treatments on the leaves carbohydrates it was noticed that, sand + clay soil give positive response in leaves carbohydrates compared with the sandy soil.

Moringa oleifera plants grown in the sand + clay soil gave the highest percentage of total carbohydrates in leaves (24.88 and $22.80 \%$ in the first and second seasons, respectively), while clayey soil recorded insignificant increases in leaves carbohydrates compared to sandy soil. A similar path was noted with El-Mahrouk et al. (2009) who studied the effect of some fertilization treatments on Cestrum aurantiacum transplants grown in pots containing sandy, clayey and sandy clayey $(1: 1 \mathrm{v} / \mathrm{v})$ soils and showed that, the highest significant value of chlorophyll (b) was obtained from plants grown in clayey soil and the highest significant total carbohydrates content was resulted from plants grown in sand + clay (1:1) soil. 


\section{A.Z. Sarhan et al.}

Table 4. Effect of growing media and fertilization treatment on carotenoids content (mg/g f.w.) of Moringa oleifera plants during 2014 and 2015 seasons.

\begin{tabular}{|c|c|c|c|c|c|c|c|c|}
\hline \multicolumn{9}{|c|}{$\begin{array}{c}\text { Growing media (B) } \\
\text { Carotenoids content (mg/g f.w.) }\end{array}$} \\
\hline \multirow[b]{2}{*}{ Fertilizer (A) } & \multicolumn{4}{|c|}{2014} & \multicolumn{4}{|c|}{2015} \\
\hline & Sandy & Clayey & $\begin{array}{c}\text { Sandy \& } \\
\text { Clayey }\end{array}$ & Mean (A) & Sandy & Clayey & $\begin{array}{c}\text { Sandy \& } \\
\text { Clayey }\end{array}$ & Mean (A) \\
\hline Control & 0.58 & 0.60 & 0.34 & 0.51 & 0.26 & 0.27 & 0.40 & 0.31 \\
\hline Microbine & 2.19 & 1.03 & 1.37 & 1.53 & 1.69 & 0.56 & 0.88 & 1.04 \\
\hline Green power & 2.52 & 0.97 & 1.79 & 1.76 & 1.97 & 1.31 & 0.90 & 1.39 \\
\hline Potasiomag & 1.82 & 1.28 & 1.46 & 1.52 & 1.65 & 0.75 & 0.60 & 1.00 \\
\hline Mean (B) & 1.78 & 0.97 & 1.24 & & 1.39 & 0.72 & 0.70 & \\
\hline LSD at 0.05 of $A$ & & 0.48 & & & & 0.30 & & \\
\hline LSD at 0.05 of $B$ & & 0.38 & & & & 0.24 & & \\
\hline LSD at 0.05 of $A \times B$ & & 0.91 & & & & 0.47 & & \\
\hline
\end{tabular}

Table 5. Effect of growing media and fertilization treatment on total carbohydrates (\%) of Moringa oleifera plants during 2014 and 2015 seasons.

\begin{tabular}{|c|c|c|c|c|c|c|c|c|}
\hline \multicolumn{9}{|c|}{$\begin{array}{c}\text { Growing media (B) } \\
\text { Total carbohydrates (\%) }\end{array}$} \\
\hline \multirow[b]{2}{*}{ Fertilizer (A) } & \multicolumn{4}{|c|}{2014} & \multicolumn{4}{|c|}{2015} \\
\hline & Sandy & Clayey & $\begin{array}{c}\text { Sandy \& } \\
\text { Clayey }\end{array}$ & Mean (A) & Sandy & Clayey & $\begin{array}{c}\text { Sandy \& } \\
\text { Clayey }\end{array}$ & Mean (A) \\
\hline Control & 16.96 & 17.30 & 22.20 & 18.82 & 16.07 & 18.89 & 19.97 & 18.31 \\
\hline Microbine & 17.69 & 22.15 & 25.25 & 21.70 & 20.08 & 21.38 & 22.66 & 21.37 \\
\hline Green power & 21.53 & 25.15 & 26.97 & 24.55 & 20.68 & 21.17 & 24.39 & 22.08 \\
\hline Potasiomag & 24.73 & 27.56 & 25.09 & 25.79 & 28.71 & 25.43 & 24.17 & 26.10 \\
\hline Mean (B) & 20.23 & 23.04 & 24.88 & & 21.39 & 21.72 & 22.80 & \\
\hline LSD at 0.05 of $A$ & & 5.39 & & & & 4.23 & & \\
\hline LSD at 0.05 of $B$ & & 4.22 & & & & 3.32 & & \\
\hline LSD at 0.05 of $A \times B$ & & 1.57 & & & & 1.23 & & \\
\hline
\end{tabular}

As for the effect of the combination of soil type and treatments of bio-fertilization, data in the first season showed that the highest values resulted from plants in clayey soil and fertilized with potasiomag which gave $27.56 \%$ compared to control plants (without fertilization and grown in the sandy soil, which gave (16.96\%) while in the second season higher values of grown plants in the sandy soil and fertilizer with potasiomag also (28.71\%) while the lowest results were recorded in control plants, which gave (16.07\%).

\section{Minerals elements $\%$ in the leaves:}

\section{a. Nitrogen (\%):}

It is clear from presented data in Table (6) that, biofertilization had a pronounced effect on increasing $\mathrm{N} \%$ in leaves compared to control. Plants received biofertilization treatments produced leaves contained $\mathrm{N}$ percentages ranged from 15.25 to $20.94 \%$ in the first seasons and from 15.66 to $25.71 \%$ in the second one, while leaves of control plants contained 8.43 and $9.23 \%$ in the first and second seasons, respectively. The high 
Table 6. Effect of growing media and fertilization treatment on nitrogen (\%) of Moringa oleifera plants during 2014 and 2015 seasons.

\begin{tabular}{|c|c|c|c|c|c|c|c|c|}
\hline \multicolumn{9}{|c|}{$\begin{array}{l}\text { Growing media (B) } \\
\text { Nitrogen (\%) }\end{array}$} \\
\hline \multirow[b]{2}{*}{ Fertilizer (A) } & \multicolumn{4}{|c|}{2014} & \multicolumn{4}{|c|}{2015} \\
\hline & Sandy & Clayey & $\begin{array}{c}\text { Sandy \& } \\
\text { Clayey }\end{array}$ & Mean (A) & Sandy & Clayey & $\begin{array}{c}\text { Sandy \& } \\
\text { Clayey }\end{array}$ & Mean (A) \\
\hline 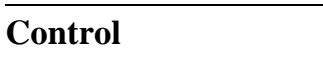 & 10.02 & 7.09 & 8.18 & 8.43 & 10.53 & 9.32 & 7.83 & 9.23 \\
\hline Microbine & 15.99 & 16.10 & 30.73 & 20.94 & 18.29 & 26.51 & 32.34 & 25.71 \\
\hline Green power & 13.17 & 18.78 & 22.71 & 18.22 & 12.67 & 21.64 & 22.35 & 18.89 \\
\hline Potasiomag & 16.64 & 16.48 & 12.63 & 15.25 & 12.99 & 15.64 & 18.34 & 15.66 \\
\hline Mean (B) & 13.96 & 14.61 & 18.56 & & 13.62 & 18.28 & 20.22 & \\
\hline LSD at 0.05 of $A$ & & 0.95 & & & & 0.91 & & \\
\hline LSD at 0.05 of $B$ & & 0.74 & & & & 0.71 & & \\
\hline LSD at 0.05 of $A \times B$ & & 1.48 & & & & 1.43 & & \\
\hline
\end{tabular}

concentration of microbine was the most effective treatment for increasing leaf $\mathrm{N} \%$ and gave 20.94 and $25.71 \%$ in the first and second seasons, respectively followed by green power which gave 18.22 and $18.89 \%$ in the first and second seasons, respectively.

Also, data in Table (6) show that, soil type, in most cases, reflected enhancement of $\mathrm{N} \%$ of leaves. The highest $\mathrm{N} \%$ (18.56 and $20.22 \%$ in the first and second seasons, respectively) were recorded with the sandy + clayey soil inoculant, followed by treatment with clayey which gave 14.61 and $18.28 \%$ in the first and second seasons, respectively. The least value of $\mathrm{N} \%$ (13.96 and 13.62\% in the first and second seasons, respectively) was generally noticed with the sandy soil plants during the two seasons. These results are consistent with what achieved by Ibrahim (2002) who found that clayey medium 100\% gave the highest chlorophyll ( $a$ and $b$ ), compared with sandy medium. Meanwhile, the sandy medium increased carotenoids, total carbohydrates content, clayey medium $100 \%$ gave the highest $\mathrm{N}$ and $\mathrm{K}$ percentages compared with sandy medium of Gasteria verrucosa and Haworthia fasciata plants.

Concerning, the interaction effect between soil type and biofertilization treatments on the $\mathrm{N} \%$ (Table, 6) a clear trend was obtained in general as all biofertilization treatments with soil type caused an increase in the $\mathrm{N} \%$ this increase was very clear with sand + clay soil and microbine. The highest mean $\mathrm{N}$ \% (30.73 and $32.34 \%$ in the first and second seasons, respectively) compared with the lowest values found in untreated plants (7.09 and $7.83 \%$ in the first and second seasons, respectively).

\section{b. Phosphorus (\%):}

Table (7) represented $P$ percentage of leaves as effected by the application of biofertilization. All biofertilization treatments had a significant effect on the increase of $\mathrm{P}$ ratio in leaves during the two seasons compared to control. Green power gave the highest percentage of $\mathrm{P}$ (7.82 and $7.75 \%$ in the first and second seasons, respectively). The lowest $\mathrm{P}$ percentage of leaves (5.71 and $6.05 \%$ in the first and second seasons, respectively) recorded in control plants.

Regarding to the effect of soil type, the obtained results showed that growing plants in clayey soil alone, remarkably increased the $\mathrm{P}$ percentage compared with growing in sandy soil plants as shown in the same Table. The least values in the sandy soil were (5.75 and $6.09 \%$ in the first and second seasons, respectively). The maximum 
Table 7. Effect of growing media and fertilization treatment on phosphorus (\%) of Moringa oleifera plants during 2014 and 2015 seasons.

\begin{tabular}{|c|c|c|c|c|c|c|c|c|}
\hline \multicolumn{9}{|c|}{$\begin{array}{c}\text { Growing media (B) } \\
\text { Phosphorus (\%) }\end{array}$} \\
\hline \multirow[b]{2}{*}{ Fertilizer (A) } & \multicolumn{4}{|c|}{2014} & \multicolumn{4}{|c|}{2015} \\
\hline & Sandy & Clayey & $\begin{array}{c}\text { Sandy \& } \\
\text { Clayey }\end{array}$ & Mean (A) & Sandy & Clayey & $\begin{array}{c}\text { Sandy \& } \\
\text { Clayey }\end{array}$ & Mean (A) \\
\hline Control & 4.99 & 6.66 & 5.49 & 5.71 & 5.62 & 6.30 & 6.22 & 6.05 \\
\hline Microbine & 5.99 & 7.31 & 6.58 & 6.63 & 6.32 & 7.67 & 7.21 & 7.07 \\
\hline Green power & 6.61 & 9.31 & 7.55 & 7.82 & 5.92 & 9.05 & 8.27 & 7.75 \\
\hline Potasiomag & 5.41 & 8.38 & 7.64 & 7.14 & 6.50 & 8.20 & 6.84 & 7.18 \\
\hline Mean (B) & 5.75 & 7.92 & 6.82 & & 6.09 & 7.81 & 7.14 & \\
\hline LSD at 0.05 of $A$ & & 1.03 & & & & 1.10 & & \\
\hline LSD at 0.05 of $B$ & & 0.81 & & & & 0.86 & & \\
\hline LSD at 0.05 of $A \times B$ & & 1.62 & & & & 1.73 & & \\
\hline
\end{tabular}

percentage of $\mathrm{P}$ (7.92 and $7.81 \%$ in the first and second seasons, respectively) were recorded with clayey soil, followed by sand + clay soil which gave 6.82 and $7.14 \%$ in the first and second seasons, respectively.

Meanwhile, using the different combinations between the previous two factors (soil type and bio-fertilization treatments) produced plants, which gave values of $\mathrm{P} \%$ very close to those obtained when each factor was used alone, i.e. the concentration of $\mathrm{P}$ on treated plants ranged from $5.41 \%$ (recorded on potasiomag treated with sandy soil) to $9.31 \%$ (obtained from plants cured with green power and cultivated with clayey soil) in the first season. This trend was more evident in the second season, the lowest concentration of $\mathrm{P}$ in combination treatments $(5.62 \%)$ was obtained for uninoculated plants grown in sandy soil whereas, the highest percentage $(9.05 \%)$ was recorded in the treatment of green power and grown in clayey soil. Control plants gave the minimum values recorded in the two seasons (4.99 and 5.62\%, respectively).

\section{c. Potassium (\%):}

Data presented in Table (8) show the effect of biofertilization treatments on leaves $\mathrm{K} \%$ and revealed that it was significantly increased due to using biofertilization treatments compared to control plants. Green power resulted in the highest $\mathrm{K} \%$ in leaves (1.83 and 2.18\%, respectively) compared to control plants (recorded 0.77 and $0.94 \%$ in the first and second seasons, respectively).

From the results it can be recognized that soil type inoculation increased $\mathrm{K} \%$ in leaves especially in case of sand + clay soil inoculation treatment where, the highest values (1.65 and $1.76 \%$ in the first and second seasons, respectively) were recorded, followed (with significant differences) by growing in sandy soils (giving value of 1.53 and $1.48 \%$ in the first and second seasons, respectively). The least $\mathrm{K} \%$ in leaves (1.28 and $1.23 \%$ in the first and second seasons, respectively) were recorded in clayey soil plants.

The interaction effect between soil type and biofertilization treatments (Table, 8) on $\mathrm{K} \%$ followed a similar trend that obtained for each factor alone, the values obtained on $\mathrm{K} \%$ were differed in a narrow range. Data show also, that plants grown in sand + clay soil and inoculated with green power had higher values (2.60 and 2.65\%, respectively) as compared with other combinations. On the other hand, in the first season, the lowest values were obtained in the control with the sandy + clayey $(0.40 \%)$ while in the second 
Table 8. Effect of growing media and fertilization treatment on potassium (\%) of Moringa oleifera plants during 2014 and 2015 seasons.

\begin{tabular}{|c|c|c|c|c|c|c|c|c|}
\hline \multicolumn{9}{|c|}{$\begin{array}{c}\text { Growing media (B) } \\
\text { Potassium (\%) }\end{array}$} \\
\hline \multirow[b]{2}{*}{ Fertilizer (A) } & \multicolumn{4}{|c|}{2014} & \multicolumn{4}{|c|}{2015} \\
\hline & Sandy & Clayey & $\begin{array}{c}\text { Sandy \& } \\
\text { Clayey }\end{array}$ & Mean (A) & Sandy & Clayey & $\begin{array}{c}\text { Sandy \& } \\
\text { Clayey }\end{array}$ & Mean (A) \\
\hline Control & 1.10 & 0.80 & 0.40 & 0.77 & 1.00 & 0.93 & 0.90 & 0.94 \\
\hline Microbine & 2.15 & 1.50 & 1.15 & 1.60 & 2.05 & 1.20 & 2.20 & 1.82 \\
\hline Green power & 1.45 & 1.45 & 2.60 & 1.83 & 2.50 & 1.40 & 2.65 & 2.18 \\
\hline Potasiomag & 1.40 & 1.35 & 2.45 & 1.73 & 0.35 & 1.40 & 1.30 & 1.02 \\
\hline Mean (B) & 1.53 & 1.28 & 1.65 & & 1.48 & 1.23 & 1.76 & \\
\hline LSD at 0.05 of $A$ & & 0.01 & & & & 0.01 & & \\
\hline LSD at 0.05 of $B$ & & 0.01 & & & & 0.01 & & \\
\hline LSD at 0.05 of $A \times B$ & & 0.01 & & & & 0.01 & & \\
\hline
\end{tabular}

season the lowest values were obtained in the treatment of potasiomag with sandy soil $(0.35 \%)$.

\section{REFERENCES}

Abd El-Aziz, M.F. (2000). Effect of Soil Types and NPK Fertilization Treatments on Azadirachta indica Seedlings. M.Sc. Thesis, Fac. Agric., Minia Univ., Egypt, $231 \mathrm{p}$.

Amaglo, N.K. (2007). Effect of spacing and harvest frequency on the growth and leaf yield of moringa (Moringa oleifera Lam.), a leafy vegetable crop. Ghana J. Hort., 6:33-40.

Arafa, W.R. (2005). Effect of Organic and Biofertilization on Growth and Active Constituents Production of Senna Plants. Ph.D. Thesis, Fac. Agric., Cairo Univ., Egypt, 181-187.

Asaolu, V.O.; Binuomote, R.; Akinlade, J.; Aderinola, O. and Oyelami, O. (2012). Intake and growth performance of West African dwarf goats fed on Moringa oleifera, Geiriciaia sepium and Leucaena leucocephala dried leaves as supplements to casava peels. J. Biol. Agric. Health Care, 2(10):76- 88.
Black, C.A.; Evans, D.D.; Ensminger, L.E.; White, G.L. and Clark, F.E. (1981). Methods of Soil Analysis. Part 2, Agron. Inc. Madison. Wisc., USA, p 1-100.

Cottenie, A.; Verloo, M.; Kiekens, L.; Velghe, G. and Camerlynck, R. (1982). Chemical Analysis of Plant and Soil. Laboratory of Analytical and Agro chemistry, State Univ., Ghent. Belgium, p 100-129.

Dash, S. and Gupta, N. (2009). Effect of inorganic, organic and bio-fertilizer on growth of hybrid Moringa oleifera (PKM). Academic Journal of Plant Sciences, 2(3):220-221.

El-Mahrouk, E.M.; Kandeel, Y.M.; Hegazi, M.A.; Nasr, Mary N. and Amani, I. Adam (2009). Effect of soil type and fertilization treatments on growth and chemical composition of some ornamental shrubs (Cestrum aurantiancum Lindley). Alex. Journal of Agriculture Research., 54(1):111-121.

El-Sayed, A.A. (2013). Effect of Soil Type, Fertilization and Salinity on Growth and Constituents of Moringa oleifera Lam. M.Sc. Thesis, Fac. Agric., Cairo University, Egypt, 107 pp. 


\section{A.Z. Sarhan et al.}

El-Sayed, A.A. and Abdou, M.A.H. (2002). Response of Khaya transplants to some soil media and biofertilization treatments. Annl. Agric. Sci., Moshtohor, 40(4):2233-2245.

Ibrahim, A.A. (2002). Effect of Growing Media and Chemical Fertilization on Growth and Chemical Composition of Gasteria and Haworthia Plants. M.Sc. Thesis, Fac. Agric., Cairo Univ., Egypt, $140 \mathrm{p}$.

Kumudha, P. (2005). Studies on the effect of biofertilizers on the germination of Acacia nilotica Linn. seeds. Advances in Plant Sciences, 18(2):679-684.

Peixoto, R.; Silva, G.C.; Costa, R.A.; Josei, L.S.; Vieira, G.H.F.; Filho, A.A.F. and Vieira, H.S.F. (2011). In vitro antibacterial effect of aqueous and ethanolic moringa leaf extracts. Asian Pacific J. Trop. Med., 4(3):201-2014.

Pontual, V.E.; Belany, E.A.C.; Bezerra, S.R.; Coelho, C.B.; Napoleao, H.T. and Paiva, M.G.P. (2012). Caseinolytic and milkclotting activities from Moringa oleifera flowers. Food Chem., 135(3-1):18481854.

Sutherland, J.P.; Folkard, G.K.; and Grant, W.D. (1989). Seeds of Moringa species as naturally occurring flocculants for water treatment. Science Technology and Development, 7(3):191-197.

Watfa, A.R. (2009). Effect of Soil Media, Nutrition and Mycorrhiza Fungi on Chemical Composition of Carob and Aleppo pine Seedlings. M.Sc. Thesis, Fac. Agric., Cairo Univ., Egypt, 156 p.

\footnotetext{
تأثير بيئة النمو والسماد الحيوي على التركيب الكيماوي لأشجار المورينجا اوليفيرا

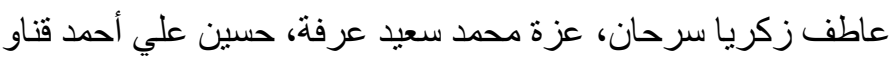

قسم بساتين الزينة، كلية الزر اعة، جامعة القاهرة، الجيزة، مصر.

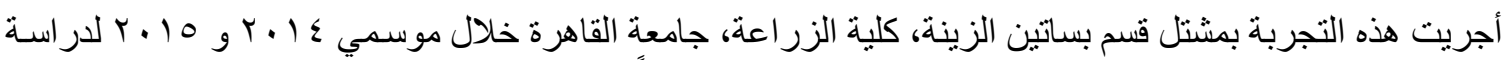

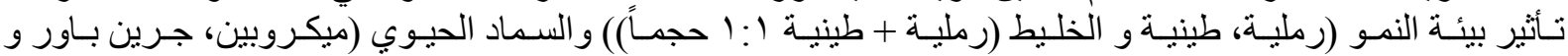

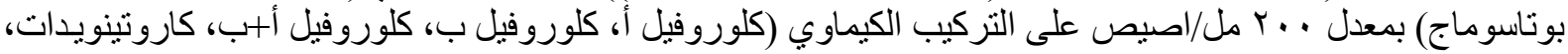

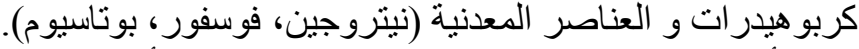

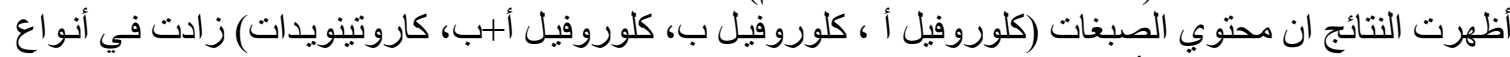

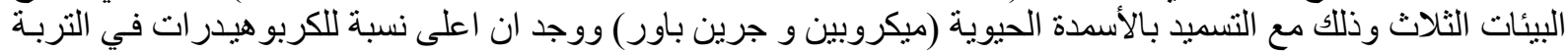

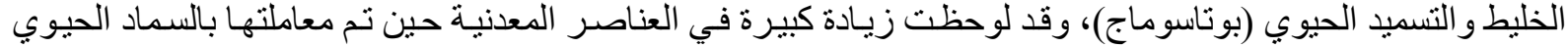
(جرين باور ) و الزر اعة في التربة الخليط.
} 